\title{
Black fungus-gnats in deciduous forest habitat in northern Europe, with the description of Bradysia arcula sp. n. (Diptera: Sciaridae)
}

\author{
Pekka Vilkamaa, Jukka Salmela \& Heikki Hippa
}

Vilkamaa, P., Salmela, J. \& Hippa, H. 2007: Black fungus-gnats in deciduous forest habitat in northern Europe, with the description of Bradysia arcula sp. n. (Diptera: Sciaridae). — Entomol. Fennica 18: 226-231.

The sciarid fauna of a deciduous forest in Kivijärvi Nature Reserve, southern Finland, was studied. In all, 58 species were found in a material of 247 specimens, collected with Malaise traps. The material included the following species new to the Finnish and North European fauna: Corynoptera postforcipata Rudzinski, Leptosciarella juniperi (Mohrig \& Blasco-Zumeta), Leptosciarella subcoarctata Mohrig \& Menzel, Leptosciarella yerburyi (Freeman), Phytosciara macrotricha (Lengersdorf) and Sciara nursei Freeman. Bradysia arcula sp. n., found also in two other localities in Finland, is described, and a key to the Finnish species of the Bradysia praecox group is provided.

P. Vilkamaa, Finnish Museum of Natural History, Zoological Museum, P.O. Box 17, FI-00014 University of Helsinki; E-mail: pekka.vilkamaa@helsinki.fi J. Salmela, Department of Biological and Environmental Sciences, P.O. Box 35, FI-40014 University of Jyväskylä, Finland; E-mail: jueesalm@cc.jyu.fi

H. Hippa, Swedish Museum of Natural History, P.O. Box 50007, SE-104 05 Stockholm,Sweden; E-mail:heikki.hippa@nrm.se

Received 9 March 2007, accepted 10 April 2007

\section{Introduction}

Several papers have been published on Sciaridae of northern Europe, but these are almost entirely focused on taxonomy (Frey 1948, Tuomikoski 1960, Hippa \& Vilkamaa 1991, 1994, 2004, 2006, Hippa et al. 2003, Vilkamaa et al. 2004, Vilkamaa \& Hippa 2005, 2006). Salmela and Vilkamaa (2005) published faunistic-ecological data on the Sciaridae of central Finland, along with some taxonomic findings. That paper was focused on coniferous forests and mires, whereas the present paper deals with deciduous forest habitat, the sciarid fauna of which is poorly known in northern Europe. Furthermore, a new species of
Bradysia, belonging to the Bradysia praecox group, is described here.

\section{Material and methods}

Kivijärvi Nature Reserve area is located in Urjala, south-western Finland (6059'N 2326'E; the square 6770:308 in the Finnish Uniform Grid System). The material was collected with two Malaise traps set in a herb-rich forest habitat on a small hill called Kalkkimäki. The site is characterized by deciduous trees (Populus tremula, Tilia cordata, Acer platanoides) but spruce (Picea abies) is also common. Several demanding and 
rare vascular plants and bryophytes, indicating a base-rich, calcareous bedrock, are known to occur in the area (for details, see Salmela \& Härmä 2004).

The traps were set in the field on 20.IV.2003 and emptied in about four week intervals; they were finally removed on 5.X.2003. We used 50\% ethylene glycol as a preservative in the traps and transferred the collected insect material later into $70 \%$ ethanol. Additional Finnish specimens of the new species were similarly collected and treated. The specimen from Canada was pinned (collection method unknown).

Sciarid males were sorted from the material and mounted on microscope slides in Euparal. The drawings were made with the help of a camera lucida attached to a Leitz Diaplan compound microscope. The material is deposited in Zoological Museum, Finnish Museum of Natural History, Helsinki $(\mathrm{MZH})$, one paratype of the new species in Deutsches Entomologisches Institut, Müncheberg (DEI), and one in Canadian National Collection, Ottawa (CNC). The nomenclature and classification follows that of Menzel and Mohrig (2000), except for genera Claustropyga (Hippa et al. 2003) and Peyerimhoffia (Vilkamaa \& Hippa 2005).

\section{Results and discussion}

\subsection{Faunistics}

The identified material consisted of 247 male specimens belonging to 58 species (Table 1). The most species-rich genera were Corynoptera and Leptosciarella (Table 1). There are actually no earlier published faunistic data on the sciarid fauna of deciduous forests in northern Europe. For the most part, the species now found have been recorded also in coniferous forest sites in Finland (see Tuomikoski 1960, Salmela \& Vilkamaa 2005) but many species, numerous in coniferous sites, were found here in very low numbers (e.g. Corynoptera boletiphaga (Lengersdorf), Camptochaeta camptochaeta (Tuomikoski) and Ctenosciara hyalipennis (Meigen).

Six species new to the Finnish fauna were found, including a new species which is described here.
Corynoptera postforcipata Rudzinski, 1993, was described from Bavaria, Germany, and has been later found in England (Menzel et al. 2006).

Leptosciarella juniperi (Mohrig \& BlascoZumeta, 1996), was described from Spain, and it has been found later in Canary Islands, Italy, Austria, Czech Republic and Turmenia (Menzel \& Mohrig 1997).

Leptosciarella subcoarctata Mohrig \& Menzel, 1997, has up to now been known only from the holotype, collected in Russia, Tuva.

Leptosciarella yerburyi (Freeman, 1983) was described from Scotland, subsequent records are from Ireland, Germany, Austria, Slovakia, Lithuania and Ukraine (Mohrig \& Menzel 1997) and from England (Menzel et al. 2006), Hungary (Rulik et al. 2001), and the Czech Republic (Menzel et al. 2000).

Phytosciara macrotricha (Lengersdorf, 1926) was described from Austria, and the species has a wide distribution from Central Europe to the Baltic countries (Mohrig \& Menzel 1994).

Sciara nursei Freeman, 1983 was described from England. The taxonomic and nomenclatural confusion regarding the complex 'nursei-marginata-flavomarginata-ulrichi' was clarified by Menzel et al. (2006). Sciara nursei (mostly under $S$. ulrichi) has a wide Palaearctic distribution (Menzel 1998, 2000, 2001, 2002 ) but our record is the first from northern Europe.

\subsection{Taxonomy}

According to Menzel and Mohrig (2000), the Bradysia praecox group is characterized e.g. by short mesial setosity of the mesonotum, palpomere 1 with simple or only indistinctly demarcated sensory area (in some species a distinct pit), palpomere 2 without long lateral setae (seems to vary between species).

\subsubsection{Key to the males of the Finnish species of the Bradysia praecox group}

1. Bases of gonocoxites with area of dense setosity, apex of tegmen with minute teeth, aedeagal teeth in groups of two or three, sensilla of palpomere 1 in patch, not in pit $\operatorname{praecox}$ (Meigen) 
Table 1. Sciaridae collected with two Malaise traps in Kivijärvi Nature Reserve, southern Finland. I-V = sampling periods: I = 20.V.-3.VI, II = 3. VI.-6.VII, II = 6.VII.-3.VIII, IV = 3.VIII.-15.IX., V = 15.IX.-5.X. The species marked with an asterisk (*) are new to the Finnish fauna.

\begin{tabular}{|c|c|c|c|c|c|}
\hline & I & II & III & IV & $\mathrm{V}$ \\
\hline Bradysia exselsa Menzel \& Mohrig, 1998 & & 1 & & 1 & \\
\hline $\begin{array}{l}\text { Bradysia hilariformis Tuomikoski, } 1960 \\
\text { Bradysia lobulifera Frey. } 1948\end{array}$ & & 12 & & & \\
\hline $\begin{array}{l}\text { Bradysia lobulifera Frey, } 1948 \\
\text { Bradysia nitidicollis (Meigen, 1818) }\end{array}$ & & 7 & 1 & & \\
\hline Bradysia rectinervis Frey, 1948 & & 1 & & & \\
\hline Bradysia fungicola gr. sp. & & & & 2 & \\
\hline${ }^{*}$ Bradysia arcula sp. n. & & 2 & & & \\
\hline Camptochaeta camptochaeta (Tuomikoski, 1960) & & 3 & & & \\
\hline Camptochaeta fallax Hippa \& Vilkamaa, 1994 & & 2 & & & \\
\hline Camptochaeta hirtula (Lengersdorf, 1934) & & 1 & & & \\
\hline Camptochaeta uniformis (Mohrig \& Menzel, 1990) & & & 2 & & \\
\hline Claustropyga heteroclausa (Rudzinski, 1991) & & & & & 2 \\
\hline Claustropyga subcorticis (Mohrig \& Krivosheina, 1985) & & 1 & & & \\
\hline Corynoptera bicuspidata (Lengersdorf, 1926) & & 1 & & & \\
\hline Corynoptera bistrispina Tuomikoski, 1960 & & 1 & 3 & 2 & 1 \\
\hline Corynoptera boletiphaga (Lengersdorf, 1940) & & 1 & & 1 & \\
\hline *Corynoptera postforcipata Rudzinski, 1993 & & & 1 & & \\
\hline Corynoptera furcifera Mohrig \& Mamaev, 1987 & & & 1 & & \\
\hline Corynoptera hypopygialis (Lengersdorf, 1926) & & & 1 & & \\
\hline Corynoptera inexspectata Tuomikoski, 1960 & & & & 1 & \\
\hline Corynoptera luteofusca (Bukowski \& Lengersdorf, 1936) & & & 2 & 1 & \\
\hline Corynoptera membranigera (Kieffer, 1903) & & & 2 & 1 & \\
\hline Corynoptera obscuripila Tuomikoski, 1960 & & 4 & 15 & 2 & \\
\hline Corynoptera subdentata Mohrig, 1985 & & 11 & 1 & & \\
\hline Corynoptera saccata Tuomikoski, 1960 & & 2 & 1 & & 1 \\
\hline Corynoptera subtilis (Lengersdorf, 1929) & & & & 2 & \\
\hline Corynoptera triacantha Tuomikoski, 1960 & & & 2 & & \\
\hline Corynoptera unidentata (Hippa \& Vilkamaa, 1994) & & & 3 & 3 & \\
\hline Ctenosciara hyalipennis (Meigen, 1804) & & 1 & & & \\
\hline Epidapus atomarius (De Geer, 1778) & & 4 & 6 & & \\
\hline Leptosciarella dimera (Tuomikoski, 1960) & 5 & 5 & & & \\
\hline Leptosciarella fuscipalpa (Mohrig \& Mamaev, 1979) & & 10 & 1 & & \\
\hline *Leptosciarella juniperi (Mohrig \& Blasco-Zumeta, 1996) & & 1 & & & \\
\hline Leptosciarella rejecta (Winnertz, 1867) & & 1 & 11 & 1 & \\
\hline $\begin{array}{l}\text { Leptosciarella scutellata (Staeger, 1840) } \\
\text { * entosciarella subcoarctata Mohria \& Menzel } 1997\end{array}$ & & 1 & 2 & & \\
\hline $\begin{array}{l}\text { *Leptosciarella subcoarctata Mohrig \& Menzel, } 1997 \\
\text { Leptosciarella trochanterata (Zetterstedt. 1851) }\end{array}$ & 1 & $\begin{array}{r}12 \\
7\end{array}$ & & & \\
\hline $\begin{array}{l}\text { Leptosciarella trochanterata (Zetterstedt, 1851) } \\
\text { *Leptosciarella yerburyi (Freeman, 1983) }\end{array}$ & & 5 & 1 & & \\
\hline Lycoriella globiceps (Becher, 1886) & 1 & & 1 & & \\
\hline Lycoriella ingenua (Dufour, 1838) & & & & & \\
\hline Lycoriella lundstromi (Frey, 1948) & & & & 1 & \\
\hline Lycoriella sp. & & 1 & & & \\
\hline Peyerimhoffia crassistylata (Frey, 1948) & & 5 & 1 & & \\
\hline Peyerimhoffia vagabunda (Winnertz, 1867) & & 2 & 3 & & \\
\hline Phytosciara macrotricha (Lengersdorf, 1926) & & & 2 & & \\
\hline Pseudolycoriella brunnea (Bukowski \& Lengersdorf, 1936) & & 1 & & 1 & 6 \\
\hline Scatopsciara tricuspidata (Winnertz, 1867) & & 4 & 2 & 2 & \\
\hline Scythropochroa radialis Lengersdorf, 1926 & & 3 & 3 & & \\
\hline Trichosia acroricha Tuomikoski, 1960 & & & 1 & 1 & \\
\hline Trichosia confusa Menzel \& Mohrig, 1997 & & & 1 & & \\
\hline Trichosia flavicoxa Tuomikoski, 1960 & & 1 & & & \\
\hline Trichosia morio (fabricius, 1794) & & 4 & 4 & 5 & \\
\hline Trichosia splendens Winnertz, 1867 & & & 3 & & \\
\hline Xylosciara heptacantha Tuomikoski, 1957 & & 1 & & & \\
\hline Xylosciara longiforceps (Bukowski \& Lengersdorf) & & 1 & & & \\
\hline Xylosciara misella (Frey, 1948) & & 1 & & & \\
\hline Zygoneura sciarina Meigen, 1830 & & 2 & & & \\
\hline Total (247) & 7 & 124 & 76 & 28 & 12 \\
\hline
\end{tabular}


- Bases of gonocoxites with normal setosity, apex of tegmen without minute teeth, aedeagal teeth solitary, sensilla of palpomere 1 in pit

2. Wing length $1.7-2.0 \mathrm{~mm}$, anal lobe of wing strong nitidicollis (Meigen)

- Wing length $>2.3 \mathrm{~mm}$, anal lobe of wing weak

3. Gonostylus broadest subapically, apical megasetae as thick and longer than apical tooth vernalis (Zetterstedt)

- Gonostylus broadest at about its middle, apical megasetae more slender and at most as long as apical tooth

4. Sensory pit of palpomere 1 small, ca. $1 / 3$ of width of palpomere 1; setosity of gonocoxite short and dense, area between apical tooth and apical megasetae setose

iridipennis (Zetterstedt)

- Sensory pit of palpomere 1 large, more than $1 / 2$ of width of palpomere 1 , setosity of gonocoxite long and sparse, area between apical tooth and apical megasetae non-setose arcula sp. n.

\subsubsection{Bradysia arcula sp. $n$.}

Material studied. Holotype male: FINLAND, Ta (Tavastia australis), Urjala, Kivijärvi Nature Reserve, Kalkkimäki $\left(60^{\circ} 59^{\prime} \mathrm{N} 23^{\circ} 26^{\prime} \mathrm{E}(=6770\right.$ : 308), grove, Malaise trap, 3.VI.-6.VII.2003, J. Salmela \& O. Härmä (MZH). Paratypes: same data as holotype, $1 \hat{\sigma}(\mathrm{MZH}) ; O b b$ (Ostrobothnia borealis), Rovaniemi, Kivalo 73587:34881, 3.VIII.2004, J. Salmela, 1 o (MZH); Obb, Tervola, Pihlajakuru W (7354251:3412039), 3.VII.2.VIII.2004, J. Salmela, 1 đ (DEI); Ta, Lahti, Mukkula, (676:92), 19.-25.VI.2002, O. Blomster, 1 đ̊ (MZH); Tb (Tavastia borealis), Konnevesi, Teerimäki, (6941:468), 21.VI.2003, J. Salmela, 1 ภ (MZH); Tb (Tavastia borealis), Saarijärvi, Pyhä-Häkki N.P., E Poika-Aho farm (62.51 N 25.26 E), spruce-pine forest, Malaise trap, 7.VI.-4.VII.2004, M. \& C. Jaschhof, 1 đ̄ (MZH); CANADA, Nova Scotia, CBHNt. Pk. Beulach Ban Fls. PG813869, wet rock face, 1.VII.1984, H.J. Teskey, 1 ऽ (CNC).

Description (male). Head. Eye bridge with 2 3 rows of facets. Interfacetal setae present. Antennal scape and pedicel dark brown. An- tennal flagellum pale brown, long. Antennal flagellomeres becoming slightly longer towards apex of flagellum; length/width of flagellomere 4 2.30-2.90 (Fig. 1a). Flagellomeres with rather densely placed setae and sensilla, longest setae about as long as flagellomeral width. Flagellomeral necks distinct, concolorous with flagellomeral bodies, shorter than wide. Prefrons and clypeus dark brown. Prefrons with 57-92 setae, short but among them some stronger ones. Clypeus with 1-8 long and strong setae. Maxillary palpus (Fig. 1b) with 3 palpomeres. Palpomere 1 long and thick, with large distinct sensillar pit with ca. 20 hyalinous sensilla densely placed; with 3-7 long setae, one of which distinctly longer than others. Palpomere 2 slightly shorter and more slender than palpomere 3, with some long and shorter sharp setae and some truncate short sensilla. Palpomere 3 possibly as long as palpomere 2 (Fig. $1 b$ may be misleading due to the orientation of the palp), with some truncate sensilla, two distal longest.

Thorax. Dark to medium brown. Thoracic setae pale and relatively fine. Acrocentrals in indistinct rows, dorsocentrals in indistinct rows of 1-3 setae, laterals in indistinct rows of 4-5 setae. Posterior pronotum bare, anterior pronotum with 10-18 setae, episternum 1 with 17-29 setae. Scutellum with numerous short, and two longer and stronger setae.

Wing. Fumose brown. Length 2.3-2.9 mm, width/length $0.40-0.45$. Anal lobe normal, small; $\mathrm{c} / \mathrm{w}$ 0.65-0.75, R1/R 0.75-0.85. Fork of $\mathrm{M}$ shorter than stM. R5 with numerous dorsal and a few ventral setae, $r-m$ with 3-6 dorsal setae, bM with 2-4 dorsal setae. stM, $\mathrm{M}$ and $\mathrm{Cu}$ non-setose. Halteres pale, with short stalk.

Legs. Pale brown, tarsi slightly darker brown; long and strong. Setae pale. Femora normal, not thickened. Length of basitarsomere 1/tibia 1 $0.55-0.60$. Tibiae, in addition to normal socketed and non-socketed setae, with some spinose setae on all sides except dorsally, T1 with a subapical prolateral comb of 4-6 (7) spinose setae (Fig. 1c). T3 with indistinct row of spinose setae ventrally at apical half, and distinct apical retrolateral row of spinose setae. Tibial spurs $1+2+2$, longer than apical diameter of tibiae, subequal in length in $\mathrm{T} 2$ and T3. Tarsal claws simple, without teeth.

Abdomen. Normal, pale brown, paler than 


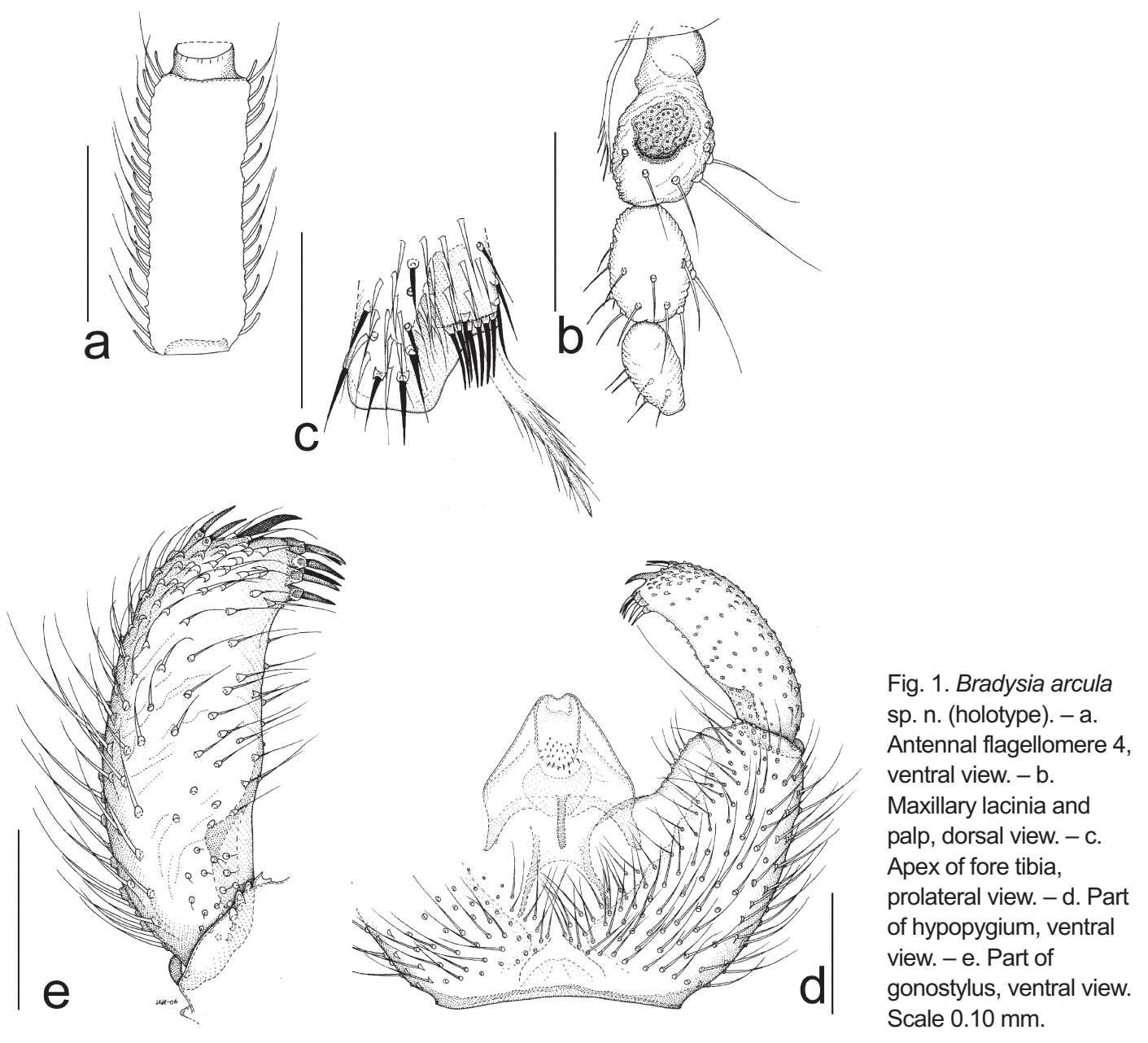

thorax, concolorous with femora and tibiae. Setae pale, slender, rather densely placed on sclerites.

Hypopygium (Fig. 1d). Pale brown. Gonocoxites separate, intercoxal area with non-setose stripe, without lobes or groups of densely placed setae. Gonocoxite non-modified, longer than broad, with a distinct long and strong seta at ventral and dorsal apicomesial corner, setae long; mesial membranous area non-setose.Tegmen about as long as wide, widest sub-basally, tapering slightly towards apex: apodemes strong and well sclerotized; parameres weakly sclerotized; apex of tegmen with membraneous area; tegmen with dorsal sclerotized oval ridge, interrupted apically. Aedeagal stalk short, strongly sclerotized, aedeagal plate with ca. 20 elongate, separate teeth. Sternite 9 with 1-2 setae.

Gonostylus (Fig. 1e). Narrow and elongate, widest submedially, slightly tapering towards apex. Apical tooth strong and curved, placed high on lateral side of apex of gonostylus. Gonostylus with two apical (lateral) and 5-6 subapical megasetae, the latter separated from apical tooth by a non-setose area. Lateral setae of gonostylus relatively short, longest ones about as long as gonostylar width.

Discussion. Bradysia arcula belongs to the Bradysia praecox group of Menzel and Mohrig (2000). Of those species of the group, which have been found in Finland (B. iridipennis, B. nitidicollis, $B$. praecox and $B$. vernalis), $B$. arcula is most similar to $B$. iridipennis by having the gonostylus broadest near its middle. $B$. arcula differs by its relatively narrower gonostylus, by having the area between the apical tooth of gonostylus and the apical megasetae non-setose, by 
having the setosity of gonocoxite sparser but longer and by having the tegmen with a dorsal sclerotized ring and by having a much larger sensillar pit on palpomere 1 .

Acknowledgements. We thank Mr. Oskari Härmä for emptying the traps in Kivijärvi and Dr. Frank Menzel, Müncheberg, for identifying some critical species, and Dr. Jeff Cummings and Dr. Mathias Jaschhof for material. PV received funding from the Research program of deficiently known and threatened forest species (PUTTE) financed by the Ministry of the Environment, Finland.

\section{References}

Frey, R. 1948: Entwurf einer neuen Klassifikation der Mückenfamilie Sciaridae (Lycoriidae). - Notul. Entomol. 27: 33-112.

Hippa, H. \& Vilkamaa, P. 1991: The genus Prosciara Frey (Diptera, Sciaridae). — Entomol. Fennica 2: 113-155.

Hippa, H. \& Vilkamaa, P. 1994: The genus Camptochaeta gen. n. (Diptera, Sciaridae). - Acta Zool. Fennica 194: 1-85.

Hippa, H. \& Vilkamaa, P. 2004: The genus Xylosciara Tuomikoski (Diptera, Sciaridae): phylogeny and revision of the species. - Acta Zool. Fennica 214: 1-38.

Hippa, H. \& Vilkamaa, P. 2006: Cladistic analysis finds a placement for an enigmatic species, Peyerimhoffia sepei sp. n. (Diptera: Sciaridae), with a note on its spermatophore. - Zootaxa 1044: 49-55.

Hippa, H., Vilkamaa, P. \& Mohrig, W. 2003: Phylogeny of Corynoptera Winnertz and related genera, with the description of Claustropyga gen. nov. (Diptera, Sciaridae). - Studia Dipterol. 9[2002]: 469-511.

Menzel, F. 1998: Sciaridae. — In: Merz, B., Bächli, G., Haenni, J.-P. \& Gonseth, Y. (eds.), Diptera-Checklist. Fauna Helvetica 1: 126-130. Schweizerische Entomologische Gesellschaft, Neuchâtel, 369 pp.

Menzel, F. 2000: Die Trauermücken - Fauna der Bundesrepublik Deutschland (Diptera: Sciaridae). — Beitr. Entomol. 50: 317-355.

Menzel, F. 2001: Sciaridae (Trauermücken). In: Menzel, F. \& Ziegler, J. (eds.), Neue Funde von Zweiflügern (Diptera) aus dem Nationalpark Hohe Tauern in Österreich nebst Angaben zum Blütenbesuch und der Be- schreibung von zwei neuen Trauermücken-Arten (Sciaridae). - Studia Dipterol. 8: 355-409.

Menzel, F. 2002: Family Sciaridae. - In: Beuk, P.L.T.(ed.), Checklist of the Diptera of the Netherlands: 64-68. KNNV, Utrecht, 448 pp.

Menzel, F. \& Mohrig, W. 2000: Revision der paläarktischen Trauermücken (Diptera: Sciaridae). — Studia Dipterol. Suppl. 6[1999]: 1-761.

Menzel, F., Mohrig, W. \& Barták, M. 2000: Sciaridae. - In: Barták, M. \& Vanhara, J. (eds.), Diptera in an industrially affected region (North-West Bohemia, Bílina and Duchcov Environs, I. - Folia Fac. Scient. Nat. Univ. Masaryk. Brun., Biol. 104: 73-81.

Menzel, F., Smith, J. E. \& Chandler, P. J. 2006: The sciarid fauna of the British Isles (Diptera: Sciaridae), including descriptions of six new species. - Zool. J. Linn. Soc. 146: 1-147.

Mohrig, W. \& Menzel, F. 1994: Revision der paläarktischen Arten von Phytosciara Frey (Diptera: Sciaridae). - Beitr. Entomol. 44: 167-210.

Mohrig, W. \& Menzel, F. 1997: Revision der paläarktischen Arten von Trichosia Winnertz sensu Tuomikoski, 1960 (Diptera, Sciaridae) - Teil II. Gattungen Leptosciarella Tuomikoski, 1960 und Trichodapus gen. nov. - Studia Dipterol. 4: 41-98.

Rulik, B., Mohrig, W. \& Jaschhof, M. 2001: Trauermücken (Diptera: Sciaridae) und freilebende Gallmücken (Diptera: Cecidomyiidae: Lestremiinae) aus Ungarn. Mit Bemerkungen zur Corynoptera tridentata-Gruppe. - Folia Entomol. Hung. 62: 231-245.

Salmela, J. \& Härmä, O. 2004: Adelphomyia punctum (Meigen, 1818) found from Finland (Diptera, Limoniidae). — Sahlbergia 9: 141-143.

Salmela, J. \& Vilkamaa, P. 2005: Sciaridae (Diptera) from central Finland: faunistics and taxonomy. - Entomol. Fennica 16: 287-300.

Tuomikoski, R. 1960: Zur Kenntnis der Sciariden (Dipt.) Finnlands. - Ann. Zool. Soc. Zool. Bot. Fennicae 'Vanamo' 21(4): 1-164.

Vilkamaa, P. \& Hippa, H. 2005: Phylogeny of Peyerimhoffia Kieffer, with the revision of the species. - Insect Syst. Evol. 35: 457-480.

Vilkamaa, P. \& Hippa, H. 2006: Corynoptera vagula Tuomikoski and allied species (Diptera: Sciaridae). Zootaxa 1150: 31-42.

Vilkamaa, P., Hippa, H. \& Komarova, L.A. 2004: The genus Dichopygina gen. n. (Diptera: Sciaridae). - Insect Syst. Evol. 35: 107-120. 